Hydrology and Earth System Sciences, 9, 185-191, 2005

www.copernicus.org/EGU/hess/hess/9/185/

SRef-ID: 1607-7938/hess/2005-9-185

European Geosciences Union

\title{
Chemical characterization of fog and rain water collected at the eastern Andes cordillera
}

\author{
E. Beiderwieden, T. Wrzesinsky, and O. Klemm \\ Institute for Landscape Ecology, University of Münster, Münster, Germany \\ Received: 22 February 2005 - Published in Hydrology and Earth System Sciences Discussions: 6 June 2005 \\ Revised: 16 August 2005 - Accepted: 31 August 2005 - Published: 14 September 2005
}

\begin{abstract}
During a three month period in 2003 and 2004, the chemistry of fog and rainwater were studied at the "El Tiro" site in a tropical mountain forest ecosystem in Ecuador, South America. The fogwater samples were collected using a passive fog collector, and for the rain water, a standard rain sampler was employed. For all samples, electric conductivity, $\mathrm{pH}$, and the concentrations of $\mathrm{NH}_{4}^{+}, \mathrm{K}^{+}, \mathrm{Na}^{+}, \mathrm{Ca}^{2+}$, $\mathrm{Mg}^{2+}, \mathrm{Cl}^{-}, \mathrm{NO}_{3}^{-}, \mathrm{PO}_{4}^{3-}$, and $\mathrm{SO}_{4}^{2-}$ were measured. For each fog sample, a 5 day back trajectory was calculated by the use of the HYSPLIT model. Two types of trajectories occurred. One type was characterized by advection of air masses from the East over the Amazonian basin, the other trajectory arrived one from the West after significant travel time over the Pacific Ocean.

We found considerably higher ion concentrations in fogwater samples than in rain samples. Median $\mathrm{pH}$ values are 4.58 for fog water, and 5.26 for the rain samples, respectively. The median electric conductivity was $23 \mu \mathrm{S} \mathrm{cm}^{-1}$ for the fog and $6 \mu \mathrm{S} \mathrm{cm}^{-1}$ for the rain. The continent samples exhibit higher concentrations of most ions as compared to the pacific samples, but these differences could not be detected statistically.
\end{abstract}

\section{Introduction}

Investigations of fog chemistry and cloud physics have become very important during the last decades. Nutrients and pollutants from fog and cloud water exhibit strong influence on ecosystems (Fisak et al., 2002). Especially in mountain forest ecosystems, where fog occurs very frequently, fog water is an important source of ion deposition (Gordon et al., 1994; Walmsley et al., 1996). The frequency of fog events typically increases with altitude above sea level

Correspondence to: E. Beiderwieden

(beiderwi@uni-muenster.de)
(Olivier and de Rautenbach, 2002; Zimmermann and Zimmermann, 2002; Holder, 2004). Prevalent fog frequencies and high wind velocities cause more fog deposition and ion input at elevated mountainous sites than in lowlands (Minami and Ishizaka, 1996; Walmsley et al., 1996; Clark et al., 1998; Igawa et al., 2002).

The scope of this study was to describe the chemical composition of fog and rain water collected in Loja/Ecuador at the eastern Andes cordillera. A characterization of the fog and rain chemistry of this region is no available yet. The study site is within the intertropical convergence zone (ITCZ), and therefore, air masses arriving from various directions represent very different advection regimes. During the sampling period from November through February, the position of the ITCZ takes course within the Ecuadorian highlands. There are basically two advection regimes (Bendix and Lauer, 1992): north easterly trade winds travelling over the Amazonian basin and south easterly trade winds deviated from the Andes cordillera. Therefore, the typical characteristics of continental and pacific air masses are assumed to disagree notably. Continentally influenced fog is suggested to contain higher concentrations of anthropogenic emissions whereas marine affected fog is assumed to yield sea salt ions such as $\mathrm{Cl}^{-}, \mathrm{Ca}^{2+}$, and $\mathrm{Mg}^{2+}$ (Munger et al., 1989; Gundel et al., 1994).

\section{Methods}

\subsection{Site description}

The fog and rainwater samples were collected from November 2003 through February 2004. The collectors were established at the "El Tiro" meteorological station at $2825 \mathrm{~m}$ a.s.l. $\left(3^{\circ} 59^{\prime} 45^{\prime \prime} \mathrm{S}\right.$ and $\left.79^{\circ} 09^{\prime} 38^{\prime \prime} \mathrm{W}\right)$, which is located in the Podocarpus National Park in southern Ecuador, South America. The sampling site is situated in the Andes highlands at

(C) 2005 Author(s). This work is licensed under a Creative Commons License. 


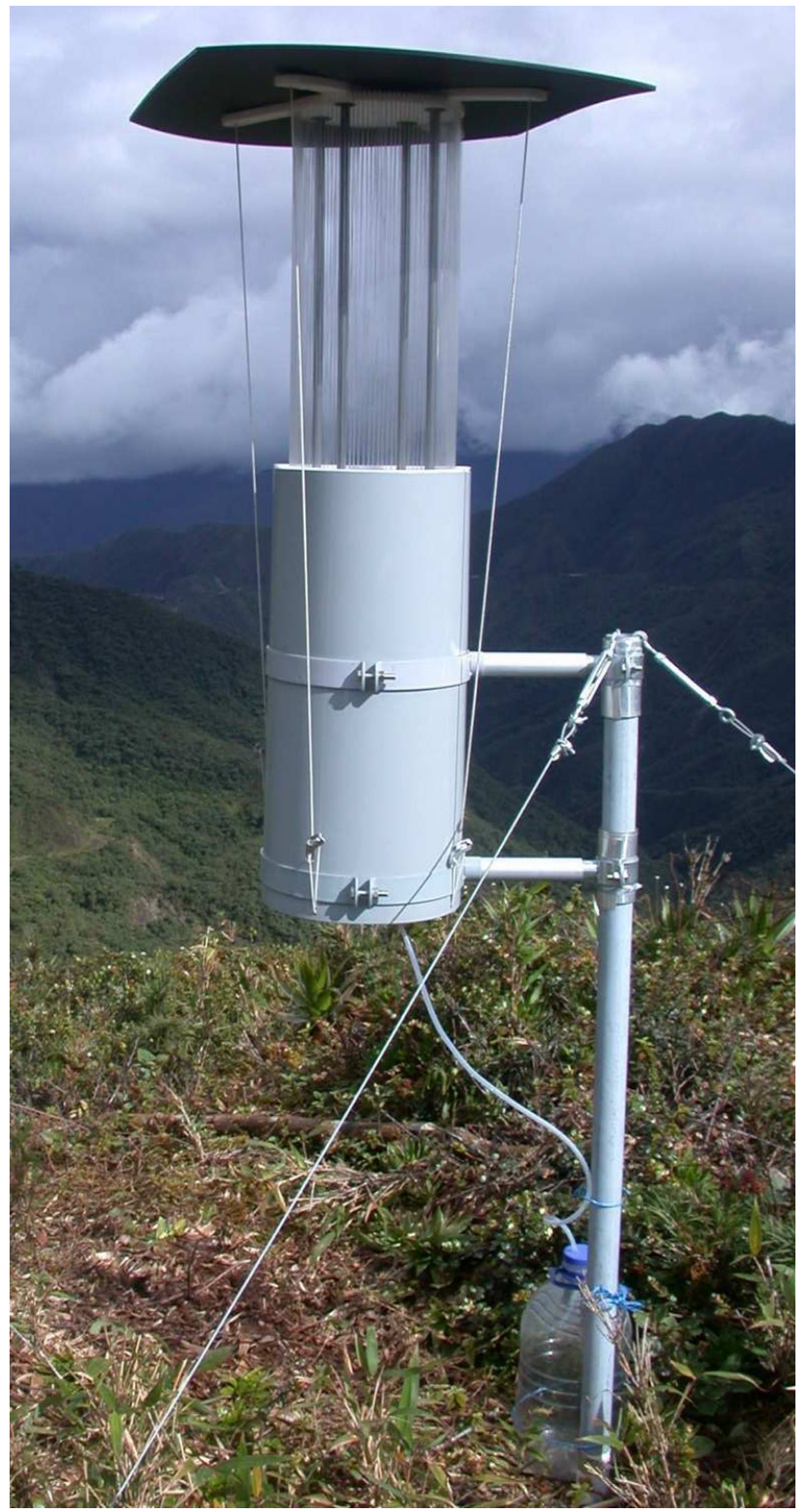

Fig. 1. Passive fog collector.

the eastern Andes cordillera. The tropical climate is characterized by marginal annual, but pronounced daily temperature fluctuations. The mean annual temperature at the "El Tiro" station is $10^{\circ} \mathrm{C}$, and the annual precipitation is about $1500 \mathrm{~mm}$. The wind regime at the sampling site is influenced by strong easterly trade winds (mean: $14 \mathrm{~m} \mathrm{~s}^{-1}$ ), with superposition of regional mountain wind systems. The frequency of fog events is very high. Winds from the Amazonian lowlands advect warm and moist air masses against the Andes massif and force them to ascent and cool adiabatically.

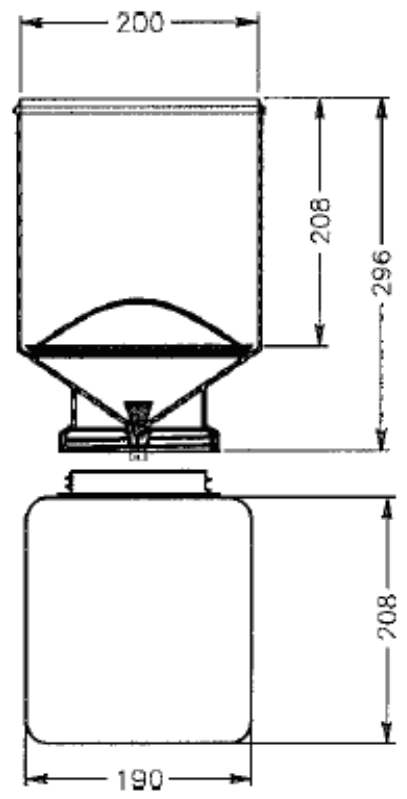

Fig. 2. Rain collector.

\subsection{Fog and rain water collection}

The fog water was sampled by using a Kroneis ${ }^{1}$ passive fogwater collector (Fig. 1). This cylindrical string collector has an effective collection surface of $945 \mathrm{~cm}^{2}$ (diameter $=21 \mathrm{~cm}$; height $=45 \mathrm{~cm}$ ). The fog droplets impact on the vertical Teflon strings, combine to larger drops, run down the strings, and drip into a $500 \mathrm{~mL}$ Polyethylene (PE) bottle. Due to the conditions of the sampling site, the roof was not effective in preventing wind-blown rain from reaching the fog sampler. The impaction of the fog droplets on the strings simulates the deposition on natural surfaces. The 460 strings are arranged cylindrically, so that the collection efficiency does not depend on the wind direction. A disadvantage of passive fog collectors is the lack of quantitative comparability of the collected fog water volumes, because there is no information about the air volume moving through the collector. Due to limited instrumentation, measurements of the liquid water content (LWC) were not possible. The fog collector was thoroughly cleaned once per week with de-ionized water.

The rainwater collector (Fig. 2) is a standard collector for chemical analyses, fabricated by $\mathrm{UMS}^{2}$. The material of the collector is PE. The collection surface is $314 \mathrm{~cm}^{2}$, and the collection bottle has a volume of $0.5 \mathrm{~L}$.

The fog samples were collected on a daily basis and the rain samples were taken once per week. For sample collection, the fog and rain water was taken from the respective collection bottle, the water volume was quantified and filled into $50 \mathrm{~mL}$ PE storage bottles. Additionally, sample aliquots

\footnotetext{
${ }^{1}$ Kroneis GmbH, Igelgasse 30-32, 1990 Wien, Austria.

${ }^{2}$ UMS GmbH, Gmunder Str. 37, 81379 München, Germany.
} 
Table 1. Limits of quantification of measured ions $\left(\mu \mathrm{eq} \mathrm{L}^{-1}\right)$.

\begin{tabular}{cc}
\hline measured ion & limit of quantification $\left(\mu \mathrm{eq} \mathrm{L}^{-1}\right)$ \\
\hline $\mathrm{NH}_{4}^{+}$ & 0.4 \\
$\mathrm{NO}_{3}^{-}$ & 0.4 \\
$\mathrm{Na}^{+}$ & 4.3 \\
$\mathrm{~K}^{+}$ & 2.3 \\
$\mathrm{Ca}^{2+}$ & 2.0 \\
$\mathrm{Mg}^{2+}$ & 0.1 \\
$\mathrm{Cl}^{-}$ & 0.8 \\
$\mathrm{PO}_{4}^{3-}$ & 2.2 \\
$\mathrm{SO}_{4}^{2-}$ & 1.0
\end{tabular}

for immediate $\mathrm{pH}$ and conductivity analyses and field blank samples were collected. All the samples were stored deepfrozen until chemical analysis in the laboratory at the University of Münster, Germany.

\subsection{Trajectories}

A common method for the identification of the origin and the pathway of air masses is to calculate backward trajectories. Trajectories are often used to study the advection of air pollutants and the coherency of the origin of air masses and their respective pollutant concentrations (Klemm et al., 1994). Air masses pick up pollutants during their travel route so that they are influenced by the geographical origin and travel path. In this study, for every fog sample a back trajectory was computed using the HYSPLIT model (Draxler and Rolph, 2003; Rolph, 2003). Each trajectory indicates the path of the respective air mass during the last $120 \mathrm{~h}$ at $1 \mathrm{~m}$ above surface level of the heavily smoothed model topography at the location where the fog collector was installed.

\subsection{Chemical analysis}

All fog and rain samples were measured for $\mathrm{pH}$, electric conductivity, and the major ions $\mathrm{NH}_{4}^{+}, \mathrm{K}^{+}, \mathrm{Na}^{+}, \mathrm{Ca}^{2+}$, $\mathrm{Mg}^{2+}, \mathrm{Cl}^{-}, \mathrm{NO}_{3}^{-}, \mathrm{PO}_{4}^{3-}$, and $\mathrm{SO}_{4}^{2-}$. The $\mathrm{pH}$ measurements were performed with a $\mathrm{pH}$ electrode (WTW $\mathrm{pH} 323$ ) and the electric conductivity with a portable conductivity meter (WTW LF 315) in separate sample aliquots. The anions $\mathrm{Cl}^{-}$, $\mathrm{NO}_{3}^{-}, \mathrm{PO}_{4}^{3-}, \mathrm{SO}_{4}^{2-}$ were measured by ion chromatography (DIONEX DX 100). $\mathrm{Ca}^{2+}$ and $\mathrm{Mg}^{2+}$ were determined by flame atomic absorption spectrometry (AAS). $\mathrm{K}^{+}$and $\mathrm{Na}^{+}$ were measured by flame photometry, and $\mathrm{NH}_{4}^{+}$by a photometric method (Aquatec Analyser). Table 1 shows the limits of quantification.

For the control of the quality of the analytical results, the measured and calculated electric conductivities were compared. For every fog and rain sample, the calculated conductivity $x_{\text {calc }}\left(\mu \mathrm{S} \mathrm{cm}^{-1}\right)$ was determined by summing up the
Table 2. Collected water samples during the field period from November 2003 through February 2004.

\begin{tabular}{cccc}
\hline- & fog water & rain water & blank \\
\hline samples & 59 & 11 & 6 \\
duplicate samples & 11 & 2 & \\
\hline
\end{tabular}

products of the specific conductivities $x_{\text {spec, } i}\left(\mu \mathrm{S} \mathrm{cm}^{-1}\right)$ and the equivalent concentrations $c_{e q, i}$ of the ions $i\left(\mu \mathrm{eq} \mathrm{L}^{-1}\right)$ :

$x_{\text {calc }}=\sum_{i} x_{\text {spec }, i} \cdot c_{e q, i}$.

Further, the ion balance was computed by summing up the equivalent concentrations of cations $i+$ and anions $i-$ of the samples. The sum of anion equivalent concentrations should be equal to that of the cations according to the condition of electric neutrality:

$$
\sum_{i} c_{e q, i+}=\sum_{i} c_{e q, i-}
$$

\section{Results}

A list of all collected samples during the sampling period from November 2003 through February 2004 is given in Table 2. Three fog samples, which were collected after extended dry conditions (fog-free periods of more than one week), had to be excluded from further analysis. These samples contained high ion concentrations that are associated with dry deposition of aerosol particles during extended nonfoggy periods on the fog collector surface before fog collection. In foggy conditions, it is adequate to clean the fog collector only once a week to avert pollution of the strings. During dry, non-foggy periods cleaning once a week is not enough to avert heavy pollution on the strings.

\subsection{Origin of the air masses}

By the use of the HYSPLIT model, for every fog sample, a $120 \mathrm{~h}$ back trajectory was calculated (Fig. 3). On the basis of these trajectories, the samples were divided into two classes. Figure 3 shows that the separation into these two groups is unequivocal. 48 fog samples were classified as "continent" samples and 8 as "pacific" samples, respectively. The continent samples originated from the Amazon basin and reached the sampling site from the East. The pathway of the continent samples is associated with north-easterly trade winds. The pacific samples travelled along the west coast of the South American continent in north-westerly direction (southeasterly trade winds) and turned to their east side before reaching the sampling site. The turnaround is suggested to result 


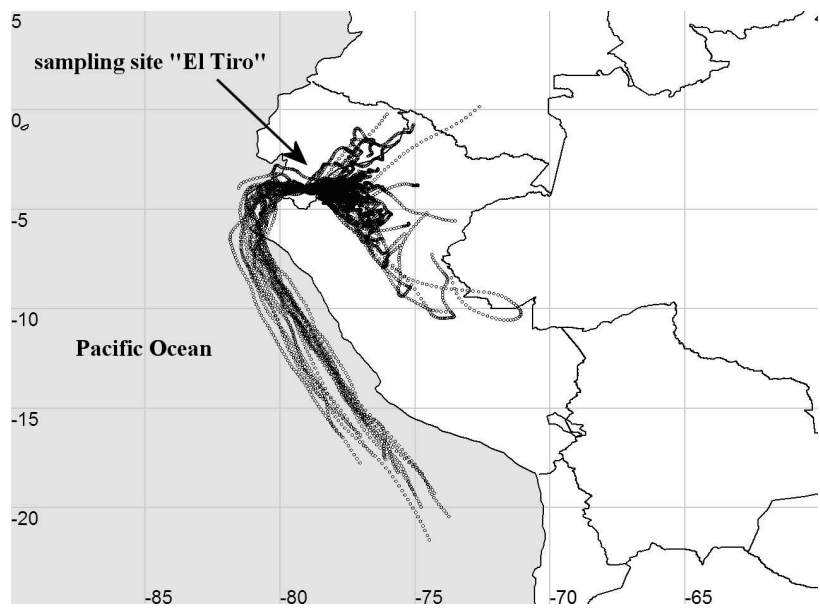

Fig. 3. $120 \mathrm{~h}$ backward trajectories for every collected fog sample.

Table 3. Electric conductivity $\left(\mu \mathrm{S} \mathrm{cm} \mathrm{cm}^{-1}\right)$, and concentrations $\left(\mu\right.$ eq $\left.\mathrm{L}^{-1}\right)$ of all the fog samples.

\begin{tabular}{cccccc}
\hline$n=56$ & median & avg & $\sigma$ & $\min$ & $\max$ \\
\hline $\mathrm{pH}$ & 4.58 & 4.46 & 0.41 & 3.91 & 5.61 \\
conductivity & 23 & 31 & 26 & 3 & 95 \\
calc. conductivity & 18 & 27 & 24 & 2 & 92 \\
$\mathrm{H}^{+}$ & 26.3 & 34.9 & 28.4 & 2.5 & 123 \\
$\mathrm{NH}_{4}^{+}$ & 30.6 & 65.0 & 83.9 & $<0.4$ & 305 \\
$\mathrm{~K}^{+}$ & 6.9 & 12.3 & 13.6 & $<2.3$ & 50.7 \\
$\mathrm{Na}^{+}$ & 8.6 & 19.5 & 25.0 & $<4.3$ & 129 \\
$\mathrm{Ca}^{2+}$ & 8.0 & 13.6 & 13.7 & 2.0 & 57.4 \\
$\mathrm{Mg}^{2+}$ & 2.3 & 6.1 & 8.8 & $<0.1$ & 43.9 \\
$\mathrm{Cl}^{-}$ & 5.5 & 9.1 & 8.8 & 0.9 & 36.1 \\
$\mathrm{NO}_{3}^{-}$ & 20.2 & 40.1 & 50.6 & 1.2 & 215 \\
$\mathrm{PO}_{4}^{3-}$ & $<2.2$ & $<2.2$ & 2.8 & $<2.2$ & 11.2 \\
$\mathrm{SO}_{4}^{2-}$ & 30.9 & 43.9 & 43.4 & 1.2 & 176 \\
$\Sigma$ cations & 82.7 & & & & \\
$\Sigma$ anions & $56.6-58.8$ & & & & \\
\hline
\end{tabular}

from local wind systems. The classification of the trajectories leads to the hypothesis that systematic differences between these two groups should exist concerning their chemical composition as a result of their different pathways.

\subsection{Chemical composition of fog water}

Table 3 shows the $\mathrm{pH}$, the electric conductivity, and the median concentrations of the 56 fog samples. The prevailing ions are the hydrogen ions $\left(\mathrm{H}^{+}\right)$, ammonium $\left(\mathrm{NH}_{4}^{+}\right)$, nitrate $\left(\mathrm{NO}_{3}^{-}\right)$, and sulphate $\left(\mathrm{SO}_{4}^{2-}\right)$. For the fog samples, the median $\mathrm{pH}$ is 4.58 and the median electric conductivity is 23 $\mu \mathrm{S} \mathrm{cm}{ }^{-1}$. The minimum and the maximum values of the measured data vary considerably. The minimum $\mathrm{pH}$ is 3.91
Table 4. $\mathrm{pH}$, electric conductivity $\left(\mu \mathrm{S} \mathrm{cm}{ }^{-1}\right)$, and concentrations ( $\mu$ eq $\mathrm{L}^{-1}$ ) of the continent fog samples.

\begin{tabular}{cccccc}
\hline$n=48$ & median & avg & $\sigma$ & $\min$ & $\max$ \\
\hline $\mathrm{pH}$ & 4.55 & 4.42 & 0.41 & 3.91 & 5.61 \\
conductivity & 25 & 32 & 26 & 3 & 95 \\
calc. conductivity & 20 & 28 & 25 & 2 & 92 \\
$\mathrm{H}^{+}$ & 28.5 & 37.8 & 29.2 & 2.5 & 123 \\
$\mathrm{NH}_{4}^{+}$ & 28.1 & 64.2 & 82.4 & $<0.4$ & 305 \\
$\mathrm{~K}^{+}$ & 6.9 & 12.5 & 14.2 & $<2.3$ & 50.7 \\
$\mathrm{Na}^{+}$ & 8.6 & 19.8 & 25.7 & $<4.3$ & 129 \\
$\mathrm{Ca}^{2+}$ & 8.0 & 13.6 & 13.9 & 2.0 & 57.4 \\
$\mathrm{Mg}^{2+}$ & 2.3 & 6.0 & 8.9 & $<0.1$ & 43.9 \\
$\mathrm{Cl}^{-}$ & 6.3 & 9.2 & 9.0 & 0.9 & 36.1 \\
$\mathrm{NO}_{3}^{-}$ & 21.0 & 40.1 & 50.2 & 1.4 & 215 \\
$\mathrm{PO}_{4}^{3-}$ & $<2.2$ & $<2.2$ & 2.9 & $<2.2$ & 11.2 \\
$\mathrm{SO}_{4}^{2-}$ & 28.8 & 42.6 & 42.0 & 1.2 & 142 \\
$\Sigma$ cations & 82.4 & & & & \\
$\Sigma$ anions & $56.1-58.3$ & & & & \\
\hline
\end{tabular}

whereas the maximum $\mathrm{pH}$ is 5.61 . For the conductivity and most of the measured ions, the picture is similar. Overall, the data set is very heterogeneous. The median total ion equivalent concentration is $139-141 \mu \mathrm{eq} \mathrm{L}^{-1}$ for the fog samples.

For the comparison of the cations and anions, the ion balance was determined. The median of the equivalent sum of the cations $\left(82.7 \mu \mathrm{eq} \mathrm{L}^{-1}\right)$ is substantially larger than the respective median sum of the anions $\left(56.6-58.8 \mu \mathrm{eq} \mathrm{L}^{-1}\right)$.

\subsection{Comparison of continent and pacific samples}

The results of the chemical analysis were tested statistically. A Kolmogorov-Smirnov-test leads to rejection of the hypothesis that the fog and rain data sets were normally distributed. Therefore, the mean values are not further discussed. Thus, the non-parametric Bootstrap-Resampling-Method was applied to produce confidence intervals of the medians of ion concentrations. According to the statistical analysis, differences between the continent and the pacific samples do exist, but are not significant ( $P$-value: 0.05$)$.

For the two groups (the continent and the pacific fog samples), ammonium, sulphate, nitrate, and the hydrogen ions are the prevailing ions (Tables 4 and 5). In general, the continent samples contain higher ion concentrations (139$\left.141 \mu \mathrm{eq} \mathrm{L}^{-1}\right)$ than the pacific samples $\left(111-113 \mu \mathrm{eq} \mathrm{L}^{-1}\right)$. The median $\mathrm{pH}$ is 4.55 for the continent and 4.93 for the pacific samples. The chemical composition of the continent samples is more heterogeneous than of the pacific samples. The minimum and maximum values for the $\mathrm{pH}$, the electric conductivity and for the measured ions diverge more for the continent samples. Tables 4 and 5 show the $\mathrm{pH}$, the electric conductivity $\left(\mu \mathrm{S} \mathrm{cm}^{-1}\right)$, and the median concentrations $\left(\mu \mathrm{eq} \mathrm{L}^{-1}\right)$ for the continent and the pacific samples. 
Table 5. $\mathrm{pH}$, electric conductivity $\left(\mu \mathrm{S} \mathrm{cm}^{-1}\right)$, and concentrations $\left(\mu\right.$ eq $\left.\mathrm{L}^{-1}\right)$ of the pacific fog samples.

\begin{tabular}{cccccc}
\hline$n=8$ & median & avg & $\sigma$ & $\min$ & $\max$ \\
\hline $\mathrm{pH}$ & 4.93 & 4.78 & 0.34 & 4.32 & 5.32 \\
conductivity & 14 & 17 & 12 & 5 & 38 \\
calc. conductivity & 10 & 14 & 11 & 4 & 34 \\
$\mathrm{H}^{+}$ & 13.2 & 16.7 & 14.3 & 4.8 & 47.9 \\
$\mathrm{NH}_{4}^{+}$ & 32.2 & 33.5 & 32.0 & $<0.4$ & 101 \\
$\mathrm{~K}^{+}$ & 4.6 & 8.4 & 9.7 & $<2.3$ & 27.6 \\
$\mathrm{Na}^{+}$ & 4.3 & 10.8 & 13.4 & 4.3 & 43.0 \\
$\mathrm{Ca}^{2+}$ & 8.5 & 8.7 & 2.9 & 5.0 & 12.0 \\
$\mathrm{Mg}^{2+}$ & 1.7 & 3.5 & 3.9 & 0.8 & 12.5 \\
$\mathrm{Cl}^{-}$ & 5.2 & 5.3 & 3.8 & $<0.8$ & 13.3 \\
$\mathrm{NO}_{3}^{-}$ & 11.5 & 19.8 & 21.2 & 1.2 & 55.6 \\
$\mathrm{PO}_{4}^{3-}$ & $<2.2$ & $<2.2$ & $<2.2$ & $<2.2$ & 4.1 \\
$\mathrm{SO}_{4}^{2-}$ & 29.6 & 30.1 & 23.3 & 2.0 & 60.4 \\
$\Sigma$ cations & 64.4 & & & & \\
$\Sigma$ anions & $46.3-48.5$ & & & & \\
\hline
\end{tabular}

\subsection{Chemical composition of rain water}

Table 6 shows the $\mathrm{pH}$, the electric conductivity, and the median concentrations of the 11 rain samples. For the rain samples, $\mathrm{SO}_{4}^{2-}$ and $\mathrm{H}^{+}$are the dominating ions. The nitrogen compounds, $\mathrm{NH}_{4}^{+}$and $\mathrm{NO}_{3}^{-}$, play only minor roles. The median value for $\mathrm{NH}_{4}^{+}$was even below the limit of quantification of $0.4 \mu \mathrm{eq} \mathrm{L}^{-1}$. The $\mathrm{pH}$ varies from 4.54 to 5.61 and the electric conductivity from $3 \mu \mathrm{S} \mathrm{cm}^{-1}$ to $11 \mu \mathrm{S} \mathrm{cm}^{-1}$. The total median ion equivalent concentration of the rain samples is $34.4-34.8 \mu \mathrm{eq} \mathrm{L}^{-1}$. The sum of the cations is $18.4-$ $18.8 \mu \mathrm{eq} \mathrm{L}^{-1}$ and the sum of the anions is $16.0 \mu \mathrm{eq} \mathrm{L}^{-1}$.

\subsection{Comparison of fog and rain water}

The chemical composition of the fog and rain samples shows pronounced differences. In Fig. 4 the median equivalent concentration of the fog and the rain samples are compared. The error bars indicate the $75 \%$ and $25 \%$ percentiles.

The total ion equivalent concentration of the fog samples is $139-141 \mu \mathrm{eq} \mathrm{L} \mathrm{L}^{-1}$ and $34.4-34.8 \mu \mathrm{eq} \mathrm{L}^{-1}$ for the rain samples, respectively. The median electric conductivity is about 4 times higher for the fog samples than for the rain samples. The largest differences concerning the ion composition exist for $\mathrm{H}^{+}, \mathrm{NH}_{4}^{+}, \mathrm{NO}_{3}^{-}$, and $\mathrm{SO}_{4}^{2-}$. The median concentrations of the $\mathrm{H}^{+}$and $\mathrm{SO}_{4}^{2-}$ are about 4 times higher in fog than in rain water. For $\mathrm{NH}_{4}^{+}$and $\mathrm{NO}_{3}^{-}$, the rates are even higher. $\mathrm{NH}_{4}^{+}$contributes $22 \%$ to the total concentration in the fog samples and is negligible in the rain samples. For the contents of $\mathrm{PO}_{4}^{3-}$, the situation is different: the median concentration is under the detection limit for the fog sam-
Table 6. $\mathrm{pH}$, electric conductivity $\left(\mu \mathrm{S} \mathrm{cm}{ }^{-1}\right)$, and concentrations ( $\mu$ eq $\mathrm{L}^{-1}$ ) of the rain samples.

\begin{tabular}{cccccc}
\hline$n=11$ & median & avg & $\sigma$ & $\min$ & $\max$ \\
\hline $\mathrm{pH}$ & 5.26 & 5.11 & 0.31 & 4.54 & 5.61 \\
conductivity & 6 & 6 & 3 & 3 & 11 \\
calc. conductivity & 4 & 5 & 3 & 2 & 13 \\
$\mathrm{H}^{+}$ & 5.5 & 7.7 & 7.5 & 2.5 & 28.8 \\
$\mathrm{NH}_{4}^{+}$ & $<0.4$ & 3.6 & 11.5 & $<0.4$ & 38.3 \\
$\mathrm{~K}^{+}$ & 2.3 & 7.1 & 9.5 & $<2.3$ & 30.0 \\
$\mathrm{Na}^{+}$ & 4.3 & 7.4 & 4.3 & 4.3 & 17.2 \\
$\mathrm{Ca}^{2+}$ & 5.0 & 6.8 & 2.9 & 3.5 & 11.5 \\
$\mathrm{Mg}^{2+}$ & 1.3 & 2.5 & 2.5 & 0.5 & 8.6 \\
$\mathrm{Cl}^{-}$ & 4.9 & 4.9 & 1.9 & 1.7 & 7.3 \\
$\mathrm{NO}_{3}^{-}$ & 0.6 & 1.8 & 2.4 & 0.4 & 8.4 \\
$\mathrm{PO}_{4}^{3-}$ & 2.4 & 4.4 & 7.5 & $<2.2$ & 25.9 \\
$\mathrm{SO}_{4}^{2-}$ & 8.1 & 7.4 & 4.9 & 1.5 & 14.8 \\
$\Sigma$ cations & $18.4-18.8$ & & & & \\
$\Sigma$ anions & 16.0 & & & & \\
\hline
\end{tabular}

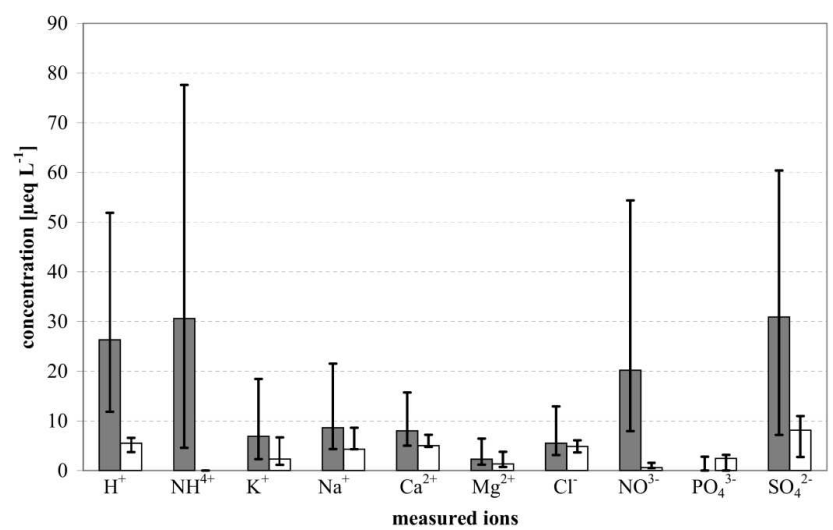

Fig. 4. Comparison of median equivalent concentrations of the fog (grey bars) and rain (white bars) samples.

ples whereas the median equivalent concentration for the rain samples is $2.4 \mu \mathrm{eq} \mathrm{L}^{-1}$. The $\mathrm{PO}_{4}^{3-}$ ions amount $7 \%$ of the total median equivalent concentration in the rain samples.

Table 7 shows the contribution of the measured ions in the fog and rain samples. $\mathrm{H}^{+}, \mathrm{NH}_{4}^{+}, \mathrm{NO}_{3}^{-}$, and $\mathrm{SO}_{4}^{2-}$ dominate in the fog water. The chemical composition of the fog samples is more heterogeneous than for the rain samples. The minimum and maximum values of the $\mathrm{pH}$, electric conductivity, and the ion concentrations diverge more for the fog than for the rain. 
Table 7. Distribution of the median equivalent contribution to the measured ion load $(\%)$ of the fog and the rain samples.

\begin{tabular}{ccc}
\hline measured ion & fog samples $(n=56)$ & rain samples $(n=11)$ \\
\hline $\mathrm{H}^{+}$ & $19 \%$ & $15 \%$ \\
$\mathrm{NH}_{4}^{+}$ & $21 \%$ & $0 \%$ \\
$\mathrm{~K}^{+}$ & $5 \%$ & $7 \%$ \\
$\mathrm{Na}^{+}$ & $6 \%$ & $13 \%$ \\
$\mathrm{Ca}^{2+}$ & $6 \%$ & $15 \%$ \\
$\mathrm{Mg}^{2+}$ & $2 \%$ & $4 \%$ \\
$\mathrm{Cl}^{-}$ & $4 \%$ & $14 \%$ \\
$\mathrm{NO}_{3}^{-}$ & $15 \%$ & $2 \%$ \\
$\mathrm{PO}_{4}^{3-}$ & $0 \%$ & $7 \%$ \\
$\mathrm{SO}_{4}^{2-}$ & $22 \%$ & $23 \%$ \\
\hline
\end{tabular}

\section{Discussion}

The analysis of the fog samples collected at the "El Tiro" site shows that there exist two classes of air mass trajectories, which are well distinguished from each other. One class represents $80 \%$ of the collected samples during the sampling period between November 2003 and February 2004. Here, the air masses travelled over the Amazonian basin before reaching the sampling site. In the other group, the air masses travel along the South American west coast over the Pacific Ocean and the coastal belt. The differences of chemical composition between continent and pacific fog water samples could not be detected as expected. Differences exist, but due to the high variability of the data and limited number of samples, these differences are not statistically significant. The sampling site is located about $100 \mathrm{~km}$ from the coast. Fog of both groups travelled over landmass on their way to the fog collector, and the pacific samples are continentally influenced as well. Therefore, a clear chemical classification of maritime and continentally influenced fog at the sampling site "El Tiro" is not possible.

Due to limited instrumentation, the liquid water content (LWC) could not be determined. Presumably, systematic differences of the LWC between the data groups might have contributed to the concentration levels by means of dilution effects.

The chemical characterization of the fog and rain samples shows distinctive differences concerning the ion composition. The most pronounced differences between the fog and the rain water exist for $\mathrm{H}^{+}, \mathrm{NH}_{4}^{+}, \mathrm{NO}_{3}^{-}$, and $\mathrm{SO}_{4}^{2-}$. These differences may result from the height of formation of the droplets as described in other studies (e.g. Bridges et al., 2002). Fog represents lower layers of the atmosphere which are stronger influenced by continental emissions. On the other hand, rain droplets, are formed at higher altitudes where the atmosphere is less loaded with compounds originating from ground-based emissions (Bridges et al., 2002).
The ions $\mathrm{H}^{+}, \mathrm{NH}_{4}^{+}, \mathrm{NO}_{3}^{-}$, and $\mathrm{SO}_{4}^{2-}$, which are the dominant ions in the fog water, are indicators for anthropogenic influence. Differences concerning the homogeneity of the fog and rain samples also may results from the characteristics of the formation. Biomass burning, industry, and traffic are suggested to be the main sources for the nitrogen compounds in the fog water. However, for the comparison of the fog and rain samples, many aspects have to be considered. The fog samples were taken on a daily basis, and the rain samples only once per week. For this reason, the rain samples represent longer time periods of seven days. Modification effects such as mixture of more concentrated with less concentrated rainwater can not be ruled out. Another reason for the differences of the chemical characteristics between the fog and rain water may be the size of the droplets. Rain drops are much larger than fog droplets and may be more diluted solutions than the fog drops. A further difference between the fog and the rain water is the unbalanced ion budget in the fog water with cations predominating over the anions. This cation surplus may result from organic acids. During the field work from November 2003 and February 2004, biomass burning was observed very close to the sampling site. Organic emissions of formic and acetic acids that could not be detected in the laboratory of the University of Münster are suggested to have caused the apparent anion deficit in the fog samples analyses. The change of land use from native forest to pasture associated with biomass burning account for an elevated ion deposition in the tropics (Keller et al., 1991). Particularly during the dry period from October through March, local emissions are transported on a regional scale and deposit on the receptor surface before they get washed out (Lanfer, 2003). In contrast, during the rainy season, local emissions rain out directly so that there is not much long-range transport. Hydrogen carbonate, $\mathrm{HCO}_{3}^{-}$, which has been shown to be an important ion in tropical fogs (Schemenauer and Cereceda, 1992), may also contribute to the ion balance of the poorly buffered samples with $\mathrm{pH}$ values around 5 . The predominance of the ions $\mathrm{H}^{+}, \mathrm{NH}_{4}^{+}, \mathrm{NO}_{3}^{-}$, and $\mathrm{SO}_{4}^{2-}$ in the fog water may result from an anthropogenic influence at the sampling site. The sampling site "El Tiro" is situated about $10 \mathrm{~km}$ to the east of the city of Loja.

\section{Conclusions}

A fog water and rain water study has been conducted in a tropical mountain forest in southern Ecuador from November 2003 through February 2004. This paper presents the results of a chemical characterization of the collected fog and rain samples. A comparison of continent and the pacific fog showed differences in ion concentrations that are statistically not significant ( $P$-value: 0.05$)$. The comparison of the fog and rain samples presents systematic differences concerning the $\mathrm{pH}$, the electric conductivity, and concentrations of most 
ions, respectively. The most pronounced differences exist for the virtual absence of ammonium and nitrate in rain water.

The location of the sampling site and limited instrumentation are suggested to be limiting factors for our measurements. For an unequivocal chemical classification into continent and pacific fog, the sampling site should be located closer to the Pacific Ocean in order to minimize possible anthropogenic influence. Therefore, the "El Tiro" site is not suitable for such measurements. Due to limited instrumentation, we did not quantify the liquid water content (LWC). Therefore we can not rule out that the origin of higher liquid water concentrations (in $\mu$ eq per litre of water) of ions in continent fog lies in the low LWC during these fog events. Knowledge about the LWC is important to compare our data with data from other studies. Furthermore, information about the droplet size distribution would help to interpret our data set.

The cation surplus may result from organic acids such as formic and acetic acids that were not determined. Biomass burning is suggested to be a possible source of these emissions.

Acknowledgements. This work was funded by the Deutsche Forschungsgemeinschaft (DFG). Special thanks are due to P. Fabian, J. Bendix, and R. Rollenbeck for their help and support. The authors gratefully acknowledge the NOAA Air Resources Laboratory (ARL) for the provision of the HYSPLIT transport and dispersion model and READY website (http://www.arl.noaa.gov/ready.html) used in this publication.

Edited by: J. Seibert

\section{References}

Bridges, K. S., Jickells, T. D., Davies, T. D., Zeman, Z., and Hunova, I.: Aerosol, precipitation and cloud water chemistry observations on the Czech Krusne Hory plateau adjacent to a heavily industrialised valley, Atmos. Env., 36, 353-360, 2002.

Bendix, J. and Lauer, W.: Niederschlagszeiten in Ecuador und ihre klimadynamische Interpretation, Erdkunde, 46, 118-133, 1992.

Clark, K. L., Nadkarni, N. M.; Schäfer, D., and Gholz, H. L.: Atmospheric deposition and net retention of ions by canopy in a tropical montane forest, Monteverde, Costa Rica, J. Trop. Ecol., 14, 27-45, 1998.

Draxler, R. R. and Rolph, G. D.: HYSPLIT (HYbrid Single-Particle Lagrangian Integrated Trajectory) Model access via NOAA ARL READY Website (http://www.arl.noaa.gov/ready/hysplit4.html), NOAA Air Resources Laboratory, Silver Spring, MD, 2003.
Fisak, J., Tesar, M., Rezacova, D., Elias, V., Weignerova, V., and Fottova, D.: Pollutant concentrations in fog and low cloud water at selected sites of the Czech Republic, Atmos. Res., 64, 75-87, 2002.

Gordon, C. A., Herrera, R., and Hutchinson, T. C.: Studies of fog events at two cloud forests near Caracas, Venezuela - II. Chemistry of fog, Atmos. Env., 28, 323-337, 1994.

Gundel, L. A., Benner, W. H., and Hansen, A. D. A.: Chemical composition of fog water and interstitial aerosol in Berkeley, California, Atmos. Env., 28, 2715-2725, 1994.

Holder, C. D.: Rainfall interception and fog precipitation in a tropical montane cloud forest of Guatemala, Forest Ecology and Management, 190, 373-384, 2004.

Igawa, M., Matsumura, K., and Okochi, H.: High frequency and large deposition of acid fog on high elevation forest, Env. Sci. Techn., 36, 1-6, 2002.

Keller, M., Jacob, D. J., Wofsy, S. C., and Harris, R. C.: Effects of tropical deforestation on global and regional atmospheric chemistry, Climate Change, 19, 139-158, 1991.

Klemm, O., Bachmeier, A. S:, Talbot, R. W., and Klemm, K. I.: Fog chemistry at the New England Coast: Influence of air mass history, Atmos. Env., 28, 1181-1188, 1994.

Lanfer, N.: Landschaftsökologische Untersuchungen zur Standortbewertung und Nachhaltigkeit von Agroökosystemen im Tieflandsregenwald Ecuadors, EcoRegio, 9, Shaker Verlag, Aachen, 2003.

Minami, Y. and Ishizaka, Y.: Evaluation of chemical composition in fog water near the summit of a high mountain in Japan, Atmos. Env., 30, 3363-3376, 1996.

Munger, J. W., Colett, J., Daube, B., and Hoffmann, M. R.: Chemical-composition of coastal stratus clouds - dependence on droplet size and distance from the coast, Atmos. Env., 23, 23052320, 1989.

Olivier, J. and de Rautenbach, C. J.: The implementation of fog water collection systems in South Africa, Atmos. Res., 64, 227238, 2002.

Rolph, G. D.: Real-time Environmental Applications and Display sYstem (READY) Website (http://www.arl.noaa.gov/ready/ hysplit4.html), NOAA Air Resources Laboratory, Silver Spring, MD, 2003.

Schemenauer, R. S. and Cereceda, P.: Monsoon cloud water chemistry on the Arabian Peninsula, Atmos. Env., 26A, 1583-1587, 1992.

Walmsley, J. L., Schemenauer, R. S., and Bridgman, H. A.: A method for estimating the hydrologic input from fog in mountainous terrain, J. Appl. Meteorol., 35, 2237-2249, 1996.

Zimmermann, L. and Zimmermann, F.: Fog deposition to Norway Spruce stands at high-elevation sites in the Eastern Erzgebirge (Germany), J. Hydrol., 256, 166-175, 2002. 